\title{
Attitudes of the police candidates according to football supporter fanaticism scale
}

\author{
Taner TUNC ${ }^{1}$, Fatih KARAKAS², Soner CANKAYA³, \\ M. Yalçin TASMEKTEPLIGIL²
}

${ }^{1}$ Ondokuz Mayis University, Faculty of Art and Science Department of Statistic, Samsun, Turkey.
2Ondokuz Mayis University, Yasar Dogu Faculty of Sports Sciences, Samsun, Turkey.
${ }^{3}$ Ordu University, Faculty of Medicine, Department of Biostatistics and Medical Informatics, Ordu, Turkey.
Address correspondence to F. Karakas, e-mail:karakasf24@gmail.com.

\begin{abstract}
The aim of this study is to determine the attitudes of the students of the Police Vocational High School about being a supporter. Football Supporter Fanaticism Scale (FSFS) was used on a total of 980 students. The coefficient of consistency was found to be 0.877 for FSFS. Factor analysis was made to test the structural validity of the study. The results of the study revealed that $1.6 \%$ of the male students were fanatic, $11 \%$ were supporters and $87.4 \%$ were spectator while $0.4 \%$ of the female students were fanatic, $7.7 \%$ were supporters and $91.9 \%$ were spectator. These results show that the future the police regards sport organizations as fun and they do not have any extreme attitudes. In order to prevent violence, such studies should occasionally be done on police department and sports club supporter groups and the tendency of individuals for violence should be assessed.
\end{abstract}

Keywords: Spectator, student, violence.

\section{INTRODUCTION}

Sport is an important social phenomenon that attracts people from all genders and all occupational groups and creates a center of attraction within itself. Besides this feature, sport has a characteristic that makes the individuals' tendencies to become supporter of a club stronger. However, sport has turned into a field including aggressive behavior and acts of violence because of the inappropriate behavior of athletes, spectators or supporters (17).

Components of violence in sports can be summarized under six headings that are supporterfanatic-hooligan-spectators, the security forces, club executives, athletes, grandstand leaders and the media $(6,12,19)$. In literature, sports fans are classified in different ways by different researchers $(3,4,6,10,16)$.

Being a supporter should be seen as a requirement of socializing and it should even be supported as long as it means to support a team within acceptable limits and without going to extremes. However, if the feelings of being a supporter reach the level of fanaticism and if it starts to hurt others, this situation should be considered a sign that sport has become not a means but a cause in the development of the individual and the society. Thus, the aforementioned view or the meaning attributed to sport by the individual or the perceptions on this matter will give an idea on what levels sport organizations ensure societal development and peace.

Fanaticism is a belief or behavior involving uncritical zeal or with an obsessive enthusiasm. The fanatical fans have obsessional tendency to support the team whereas the dysfunctional fans achieve a definite self-identification from their team or club of support $(11,15,18)$. They play a big role to support their team, therefore they willing to buy a ticket and attending every game at the stadium (23).

Police is a public officer who provides services of safety, who protects the lives and properties of citizens as well as their basic rights and freedom and 
public order and who enforces the law Police has an active duty in the prevention of violence in sport as well as a great number of events. As a matter of fact, it is natural for the police to commune with a sport club, to love that club and therefore to support that club. Within this framework, the attitudes of the police on being supporters of football clubs are very important since they are responsible for maintaining safety and order in the society and for preventing behaviors not suitable for legislation (20). The police are primarily responsible for maintaining sport activities in peace and ensuring the safety of spectators. İt is very important not to provoke the citizens or not to be provoked by them while carrying out their duties (5).

The aim of this study is to determine the attitude of the students of Samsun Ondokuz Mayis Police Vocational High School about being a supporter.

\section{MATERIAL \& METHOD}

This study was conducted on a total of 980 students of Samsun Ondokuz Mayıs Police Vocational High School, 499 male and 481 female. In order to determine the attitude of the students, Football Supporter Fanaticism Scale (FSFS) developed by Taşmektepligil et al. $(21,22)$ was used. The scale has 13 items which were prepared in the form of four-point Likert scale (totally agree $=1$, agree $=2$, disagree $=3$, totally disagree $=4$ ). The first 8 items of the scale, the first factor, express the supporters' "thought and action tendencies of violence" The last five items of the scale, the second factor, express the supporters' "attitudes towards institutional belonging" (Table 1). In terms of football, fanatics are the kind of spectators who think that everything is fair to win, who are not interested in the aesthetic and beauty of sport, just care about the result, the colors and songs of their team, etc. $(2,7,9)$. If the total score of the students ranges 13-21, they are called as "fanatic"; if their score ranges 22-30, they are also called as "supporter" and if their score ranges 31-52, they are "spectator".

In order to ease the use of the questionnaire which was conducted on the students of Police Vocational High School to determine their attitudes on the competitive conditions of football, the answers of the questionnaire were coded as a) Totally Agree, b) Agree, c) Disagree and d) Totally Disagree and the codes were given scores of 1, 2, 3, 4, respectively starting from " $a$ ".

Before the study, the required ethics committee approval obtained from Turkish National Police Academy (2013/91265). The aim of this study was explained to the individual during the data collection phase, and thus the "informed consent principle" was fulfilled.

\section{Statistical analysis}

Firstly, reliability analysis (Cronbach's Alpha) was performed to determine the internal consistency of the data. Secondly, factor analysis was performed to test the structural validity of the questionnaire. Finally, the descriptive statistics for the research data were estimated based on FSFS criteria, the differences between the answers to the questions in terms of gender and being in a supporter group were determined by Student $t$-test. All the computational work was performed by means of SPSS $21.0 \mathrm{~V}$.

Table 1. Football supporter fanaticism scale.

1. I consider physical violence against the supporters of the opponent team as natural
2. My team should try every way in order to win, including illegal ways
3. Most of the time, I cheer against the players of the opponent team or the referee from the tribune
4. If I see a supporter of the opponent team outside with the team's colors, I can hardly contain myself not to beat him up
5. I can throw foreign objects in the field when I get angry during the game
6. If a fight breaks with the spectators of the opponent team, I can get in the fight without reserve
7. If the game has got out of hand, I can sometimes enter the field without reserve
8. I get very angry with the comments of the commentator against my team during a live game
9. I go to a game with outfits that show the symbols of my team
10. I go to stadiums to watch my team's games
11. I cheer during a game in the stadium
12. I sometimes do not see a goal because of paying attention to the tribunes
13. I try to persuade people and children who are not supporters of a team to support my team


Table 2. Descriptive statistics and factor loading of FSFS items.

\begin{tabular}{|c|c|c|c|c|}
\hline FACTORS & \multirow{2}{*}{ Mean } & \multirow{2}{*}{$\mathrm{SD}$} & \multirow{2}{*}{ Median } & \multirow{2}{*}{$\begin{array}{l}\text { Factor } \\
\text { Loading }\end{array}$} \\
\hline Factor $1-$ Tendency of Thought and Action Oriented to Violence & & & & \\
\hline I consider physical violence against the supporters of the opponent team as natural & 3.36 & 0.82 & 4 & 0.775 \\
\hline My team should try every way in order to win, including illegal ways & 3.37 & 0.84 & 4 & 0.678 \\
\hline $\begin{array}{l}\text { Most of the time, I cheer against the players of the opponent team or the referee from the } \\
\text { tribune }\end{array}$ & 3.24 & 0.86 & 3 & 0.645 \\
\hline $\begin{array}{l}\text { If I see a supporter of the opponent team outside with the team's colors, I can hardly contain } \\
\text { myself not to beat him up }\end{array}$ & 3.46 & 0.80 & 4 & 0.790 \\
\hline I can throw foreign objects in the field when I get angry during the game & 3.40 & 0.85 & 4 & 0.751 \\
\hline If a fight breaks with the spectators of the opponent team, I can get in the fight without reserve & 3.33 & 0.89 & 4 & 0.782 \\
\hline If the gane has got out of hand, I can sometimes enter the field without reserve & 3.39 & 0.83 & 4 & 0.805 \\
\hline I get very angry with the comments of the commentator against my team during a live game & 2.66 & 0.91 & 3 & 0.717 \\
\hline \multicolumn{5}{|l|}{ Factor 2- Institutional Belonging (Using the symbols of the team, integrating with the supporters etc.) } \\
\hline I go to a game with outfits that show the symbols of my team & 2.52 & 1.01 & 2 & 0.834 \\
\hline I go to stadiums to watch my team's games & 2.87 & 0.88 & 3 & 0.741 \\
\hline I cheer during a game in the stadium & 2.57 & 0.95 & 3 & 0.783 \\
\hline I sometimes do not see a goal because of paying attention to the tribunes & 3.06 & 0.87 & 3 & 0.467 \\
\hline I try to persuade people and children who are not supporters of a team to support my team & 2.68 & 1.01 & 3 & 0.614 \\
\hline
\end{tabular}

The fact that the scoring average of the students for each question was more than 2 shows that the students are not fanatic or supporter, but they are spectator. $6.8 \%$ (67) of the students got the highest score from FSFS $(13 \times 4=52)$ while $0.4 \%$ (4) got the lowest score $(13 \times 1=13)$.

According to the criteria of fanaticism scale, 1.6\% of the male students were found to be "fanatic", $11 \%$ were found to be "supporter" and $87.4 \%$ were found to be "spectator" while $0,4 \%$ of the female students were found to be "fanatic", $7.7 \%$ were found to be "supporter" and $91.9 \%$ were found to be "spectator" (Table 3). On the other hand, when the numeric distribution of the students were examined in terms of their being member of a supporter group, it was found that only 1 of the 8 "fanatic" male students was not a member of a supporter group while of the 55 "supporters" 25 were a member of a supporter group and 30 were not. Similarly, it was found that 55 of the 436 "spectator" male students were a member of a supporter group, 381 were not. None of fanatic female students were members of a supporter group while 5 of the supporters and 38 of the spectator female students were members of a supporter group. 91\% (438/481) of the female students were not found to be members of a supporter group (Table 4).

Table 3. Distribution of the students based on the supporter fanaticism scale.

\begin{tabular}{lccc}
\hline Status of supporter & $\begin{array}{c}\text { Male } \\
\mathrm{n}(\%)\end{array}$ & $\begin{array}{c}\text { Female } \\
\mathrm{n}(\%)\end{array}$ & $\begin{array}{c}\text { Total } \\
\mathrm{n}(\%)\end{array}$ \\
\hline Fanatic & $8(1.6)$ & $2(0.4)$ & $10(1.0)$ \\
Team supporter & $55(11.0)$ & $37(7.7)$ & $92(9.4)$ \\
Spectator & $436(87.4)$ & $442(91.9)$ & $878(89.6)$ \\
Total & $499(100.0)$ & $481(100.0)$ & $980(100.0)$ \\
\hline
\end{tabular}

Table 4. Distribution of the students based on their being members of a supporter group.

\begin{tabular}{lcccc}
\hline \multirow{2}{*}{ Status Supporter } & \multicolumn{2}{c}{$\begin{array}{c}\text { Status of being a supporter } \\
\text { for male students }\end{array}$} & $\begin{array}{c}\text { Status of being a supporter } \\
\text { for female students }\end{array}$ \\
\cline { 2 - 5 } & Yes & No & Yes & No \\
\hline Fanatic & 7 & 1 & - & 2 \\
Team supporter & 25 & 30 & 5 & 32 \\
Spectator & 55 & 381 & 38 & 404 \\
Total & 87 & 412 & 43 & 438 \\
\hline
\end{tabular}


Table 5. Total score distribution and Student $t$-test results of students in terms of gender and being member of a supporter group.

\begin{tabular}{|c|c|c|c|c|}
\hline \multirow[b]{2}{*}{ Gender } & \multicolumn{2}{|c|}{ Being member of a supporter group } & \multirow[b]{2}{*}{$\begin{array}{c}\text { Total } \\
\text { Mean (n) }\end{array}$} & \multirow[b]{2}{*}{ P-value } \\
\hline & $\begin{array}{c}\text { Yes } \\
\text { Mean (n) }\end{array}$ & $\begin{array}{c}\text { No } \\
\text { Mean (n) }\end{array}$ & & \\
\hline Male & $33.02(88)$ & $40.16(411)$ & $38.90(499)$ & \multirow{3}{*}{$<0.001$} \\
\hline Female & $37.70(43)$ & $41.23(438)$ & $40.92(481)$ & \\
\hline Total & 34.56 (131) & $40.71(849)$ & $(980)$ & \\
\hline
\end{tabular}

Significant differences were found between male and female students in terms of their answers to the questionnaire both in individual questions and in terms of their total scores $(\mathrm{P}<0.001)$. Average score of the male students was found 2.02 points lower than female students. Have a significant difference of 7.14 points was found between male students who were members of a supporter group and those who were not members of a supporter group $(\mathrm{P}<0.001)$. A significant difference of 3.53 points was found between female students who were members of a supporter group and those who were not members of a supporter group $(\mathrm{P}=0.002)$. In addition to these, a significant difference was found when the variable of being member of a supporter group was examined regardless of gender $(\mathrm{P}<0.001$; Table5).

\section{DISCUSSION}

The contribution of the police in minimizing the aggressive behaviors in football stadiums and the harms of these behaviors is extremely important in a lot of ways such as the success of police in earning the trust, support and sympathy of people (8). In the reliability analysis which was made in order to present the internal consistency of the answers of students to the questionnaire, the reliability coefficient (Cronbach's Alpha) was found 0.877, which is above the value of 0.70 , a value that is considered to be enough to gain reliability (1).

According to the items of the FSFS, $0.4 \%(n=4)$ of the students got 13 points and they were found to be in the farthermost part of the fanaticism total score interval [13-21]. On the other hand, $7 \%(n=67)$ of the students got 52 points and they were found to be in the farthermost part of the spectator score interval [3152]. Most of the Police Vocational High School students $(89.6 \%)$ were found to show a positive attitude in terms of spectator behaviors. In Kaynak's (2002) study, police officers stated with a high percentage of $91.1 \%$ that it was out of question for them to behave tolerant and privileged to the spectators of the team they were supporting when they were performing their duty in their team's match. The results of the same study also show that when the police were performing their duty in a match of their team, to a great extent they thought it was natural when their team lost (13). In another study, it was also determined that a great majority of police officers $(91.5 \%)$ who participated in the questionnaire stated that supporting a team did not affect their attitudes and behaviors on how they reacted to events in a stadium where they were on duty. These two studies support the findings of this study (2). This finding show that the young people who will start to work as police see sport organizations more like fun rather than having excess attitudes and behaviors. In terms of preventing violence and bringing it to an acceptable level, it will be of great use to give such questionnaires to find out violence tendencies to all the police department and sport club supporter groups and to find out the individuals' fanaticism tendency scores. In addition to this, it was found that female students showed a $4.5 \%$ higher distribution of being spectator when compared with male students. In terms of the answers of the questionnaire, a significant difference was found in both individual questions and also in total score between female and male student. This result shows that female students will present a more objective point of view in the games played by the teams they are interested in. It was indicated that female supporters had lower violence and aggressiveness tendencies, lower levels of being affected by their team's loss, lower levels of supporting their team and lower levels of being affected by events and being provoked when compared with male supporters (14). This result shows that female supporters have lower tendencies of violence and hooliganism when compared with male supporters. 
In conclusion, it can be said that female supporters will be less affected from arguments related to fanaticism. In addition to these, a significant difference was found between the FSFS scores of those who were members of a supporter group and those who were not. Being supporters may psychologically affect the police on duty in games. In this study, the FSFS scores of those included in the supporter group were found to be lower. Thus, being a member of a supporter group is considered to be a feature that needs to be checked.

As is known, majority of the police officers on duty in a sports game are police officers working under the command of mobile force division. In general, the officers in mobile force division are chosen among the newly graduates of Police Vocational High School students. Periodic courses, conferences and/or educational seminars on sport sociology and sport psychology can decrease the violence tendencies of students inclined to fanaticism.

\section{REFERENCES}

1. Altunişik R, Coskun R, Yıldırım E, Bayraktaroglu S. Sosyal Bilimlerde Arastirma Yontemleri, SPSS Uygulamalı, Gelistirilmis 5. Baski. Adapazari: Sakarya Kitabevi, 2007.

2. Arıan Y. Futbolda siddet ve polis. Polis Bilimleri Dergisi, Ankara, 2007; 9 (1-4):109-132.

3. Bridgewater S. Football Brands. Palgrave Macmillan, Warwick Business School, University of Warwick, UK, 2010.

4. Capella ME. Measuring sports fans 'involvement: the fan behavior questionnaire. Southern Business Review, 2002; 27(2): 30-36.

5. Cerrah İ, Sevindik M, Kavruk M. Güvenlik Gücleri İcin Yakın Savunma Teknikleri. Ankara: Baskent Klise ve Matbaacılık, 1998

6. Dionisio P, Leal CandMautinho L. Fandom Affiliation Tribal Behavior: A Sports Marketing Application. Qualitative Market Research: An International Journal, 2008;11(1): 17-39.

7. Erkal M, Baloglu E, Baloglu F. Ansiklopedik Sosyoloji Sözlügü. İstanbul: Der Yayinlari,1997.

8. Findikli R. Polis meslegininozelliklerivemeslekikimlikolgusu. Polis BilimleriDergisi, 2000; 2(5-6):1-16.9

9. Fisek K. İc Barısın Bütün Sartları Mevcut! Hurriyet Gazetesi (18 Kasim 1997). Last access address: http://www.hurriyet.com.tr/ic-barisin-butun-sartlari-mevcut-139274236, Last access date: 07.03.2016.
10. Greenwell TC, Brownlee E, Jordan JS and Popp N. Service fairness in spectator sport: the importance of voice and choice on customer satisfaction. Sport Marketing Quarterly,2008; 17(2): 71-78.

11. Hunt AK, Bristol T and Bashaw RE. A conceptual approach to classifying sports fans'. Journal of Services Marketing, 1999; 13(6): 439-452.

12. Kaplan T. Dimensions of violence in soccer. Journal of Sports and Performance Researches,2016; 7(1): 1-10.

13. Kaynak I. The Police Who Make a Duty in the Sport Competition is Searched Their Behavior and Manner, Master Thesis, Gazi University, Institute of Health Sciences, Department of Physical Education and Sport, Ankara, 2002.

14. Kocer M.Mapping violence and hooliganism tendencies of football fans who are registered to football associations: the sample of Kayseri. Erciyes University Journal of the Institute of Social Sciences,2012;32 (1):111-135.

15. Marimaa K. The many faces of fanaticism. ENDC Proceedings, 2011,14: 29-55.

16. Ngan HMK, Prendergast GP and Tsang ASL. Linking sports sponsorship with purchase intentions: team performance, stars, and the moderating role of team identification. European Journal of Marketing, 2011; 45(4): 551-566.

17. Özsoy S. Sporda Siddet ve Medya, Tum Yönleri ile Siddet Calıstayi Tebligleri. (Ed. Eyigün S, Oral B, Günay R, Basaran S, Yıldız H, Efe R) Diyarbakır: Dicle Üniversitesi Basımevi, 2013: 105.

18. Palsa J. Customer Relationship Management in Sport Business: Case: The Spectator Profile of the Finnish National Football Team, JAMK University of Applied Sciences, Bachelor's thesis, Finland, 2015.

19. Pimentel RW and Reynolds KE. A model for consumer devotion: affective commitment with proactive sustaining behaviors. The Academy of Marketing ScienceReview,2004; 5: 1-35.

20. Resmigazete. 2559 Sayili Polis Vazife ve Selahiyet Kanunu, 1934.

21. Tasmektepligil MY, Cankaya S, Tunc T. Futbol Taraftarı Fanatiklik Olcegi, Tolerance in Violence Out: Sporda Siddetin Temelleri ve Önlenmesi Yönündeki Stratejiler Sempozyumu, 67 Haziran, Samsun, 2013.

22. Tasmektepligil MY, Cankaya S, Tunc T. Fanaticism scale for football fans. Journal of Sports and Performance Researches, 2015; 6(1): 41-49.

23. Yusoff NH. Types of deviant behavior among football fans in Malaysia. Mediterranean Journal of Social Sciences, 2016; 7(1): 59-62. 